\title{
Cancer risk and overall survival in mismatch repair proficient hereditary non-polyposis colorectal cancer, Lynch syndrome and sporadic colorectal cancer
}

\author{
Pilar Garre • Lorena Martín • Inmaculada Bando • Alicia Tosar • \\ Patricia Llovet · Julián Sanz • Atocha Romero • Miguel de la Hoya • \\ Eduardo Díaz-Rubio • Trinidad Caldés
}

Published online: 6 September 2013

(C) Springer Science+Business Media Dordrecht 2013

\begin{abstract}
Mismatch repair proficient hereditary non-polyposis colorectal cancer (MSS-HNPCC) encloses a heterogeneous group of families consisting of different unknown genetic syndromes and/or aggregations cases. The lack of information about the hereditability of cancer risk in these families makes it difficult to carry out an individualized Genetic Counseling. Therefore, deep description of such families becomes important for a better classification and search for underlying susceptibility causes. The aim of this study is to describe and compare the clinical, morphological features, tumor KRAS status and overall survival in MSSHNPCC, Lynch and sporadic colorectal cancer. A total of 37 MSS-HNPCC families, 50 Lynch families and 612 sporadic CRC were included. Clinical and morphological data were evaluated by reviewing medical and pathology reports of 55, 69 and 102 tumors respectively. KRAS/BRAF status were detected by allele specific real-time PCR. Standardized
\end{abstract}

Electronic supplementary material The online version of this article (doi:10.1007/s10689-013-9683-2) contains supplementary material, which is available to authorized users.

P. Garre $(\bowtie) \cdot$ L. Martín · I. Bando · A. Tosar · P. Llovet .

A. Romero · M. de la Hoya · T. Caldés $(\varangle)$

Laboratorio de Oncología Molecular, Servicio de Oncología

Médica, Hospital Clínico San Carlos, IdISSC, c/Profesor Martín

Lagos s/n, 28040 Madrid, Spain

e-mail: pilar_garre@hotmail.com

T. Caldés

e-mail: trinidad.caldes@salud.madrid.org

J. Sanz

Servicio de Anatomía Patológica, Hospital Clínico San Carlos, IdISSC, c/Profesor Martín Lagos s/n, 28040 Madrid, Spain

E. Díaz-Rubio

Servicio de Oncología Médica, Hospital Clínico San Carlos, IdISSC, c/Profesor Martín Lagos s/n, 28040 Madrid, Spain incidence ratios (SIR) were calculated among 602 MSSHNPCC relatives and 668 Lynch relatives. Main features distinguishing MSS-HNPCC were diagnosis age $(55.1 \pm 12.6)$, preferential distal location $(76 \%)$, polyp detection (45\%) and familial colorectal cancer incidence $(\mathrm{SIR}=6.6)$. In addition, we found increased incidences rates for kidney, stomach and uterus tumors. KRAS mutation rates were similar in the study populations $(48.8 \pm 5.8)$ but higher than those described before by Sanger sequencing. MSS-HNPCC overall survival was similar to Lynch in B Dukes' stage tumors and between Lynch and sporadic in C stage tumors. Anatomical and morphological data of MSSHNPCC are consistent with other described populations. Our studies disclose an increased HNPCC-extracolonic tumors incidence and improved overall survival in MSSHNPCC families.

Keywords HNPCC $\cdot$ MSS $\cdot$ SIR $\cdot$ Survival $\cdot$ KRAS

\section{Introduction}

Hereditary nonpolyposis colorectal cancer (HNPCC) has been defined as a familial syndrome with an increased incidence of colorectal cancer (CRC) and/or other extracolonic tumors [1, 2]. Amsterdam I [3] and II [4] criteria were initially developed to describe common clinical features of HNPCC families. Approximately half of HNPCC cases are caused by DNA mismatch repair (MMR) pathway defects [5, 6]. Germline mutations in MMR genes ( $M L H 1$, MSH2, MSH6, and PMS2) are responsible for these cases and they are commonly referred to as Lynch syndrome. The other half of the Amsterdam families have no evidence of MMR deficiency; CRC in affected members are microsatellite stable (MSS) and MMR mutations are not 
found. This fact makes it difficult to carry out an individualized Genetic Counseling in all these families.

It has been 7 years since Lindor and collaborators proposed the term "Familial Colorectal Cancer type X" to define these MSS-HNPCC families which show an autosomal dominant pattern of inheritance (Amsterdam I criteria) and proficient MMR tumors [7]. They established this group (FCC-X) as a distinct entity from Lynch syndrome with a lower risk of colorectal cancer and an older average age at diagnosis though still much younger than sporadic cases [7]. Only a few studies have been published later about strict FCC-X families or MSS-HNPCC with less stringent criteria (Amsterdam II o Bethesda criteria). All of them supporting the older age at CRC diagnosis and furthermore, displaying a preferential distal location of colorectal tumors and greater proportion of patients with polyp detection at the time of CRC diagnosis [7-16]. A previous study of our group showed that these families have distinctive molecular profiles [15]. Despite these features, all authors agree that MSS-HNPCC is a heterogeneous group of families consisting of different genetic syndromes and some cancer aggregations. In fact, in our laboratory we have attempted to explain the cancer susceptibility of these families through the screening of genes involved in the Base Excision Repair pathway and we found only a limited number of families whose cancer risk could be explained by gene variants in this pathway [17]. Therefore, deeper description of such families in different populations remains crucial for a better classification of this group and search for underlying susceptibility causes.

Percentage of KRAS somatic mutation reported by Sanger sequencing in CRC vary from 17 to $47 \%$ in MSSHNPCC tumors, 27 to $40 \%$ in Lynch and $30-40 \%$ in sporadic tumors $[8-10,15,18]$. BRAF mutations have been found in $8-20 \%$ of sporadic CRC [19-21] and almost never in HNPCC families [8, 10, 22]. Recently they have been developed new techniques for somatic mutation detection based in different technologies. These high sensitive methods can detect until $1 \%$ of tumor cells and about $50 \%$ of colorectal cancer has shown KRAS exon 2 mutations by these methods [23-25]. Last year the food and drug administration (FDA) approved the "Therascreen KRAS RGQ PCR Kit", recommended test to determine whether or not patients with advanced colorectal cancer have a wild-type KRAS gene, indicating eligibility for antiEGFR monoclonal antibody therapy [26]. Due to the significance of both predictive biomarkers, KRAS and BRAF, in the oncology clinical practice and the advancement of the above technologies, we find it convenient to reanalyze $K R A S / B R A F$ mutations in our cohort of MSS-HNPCC by high sensitive methodology.

The aim of this study is to describe and compare the clinical, morphological features and tumor KRAS/BRAF status in MSS-HNPCC, Lynch syndrome and sporadic colorectal cancer.

\section{Methods}

Study populations

\section{MSS-HNPCC population}

A total of 37 families out of 499 families were recruited at the Genetic Counseling Unit of our Hospital from 1999 to 2010. All studied tumors from these families were MSS, showed normal expression of MMR proteins and no pathogenic mutation was detected in none of the 4 MMR genes. Seventeen families fulfilled Amsterdam I clinical criteria [3], 9 fulfilled Amsterdam II criteria [4] and 11 families fulfilled our own defined high-risk criteria (HRC). We consider HRC families those fulfilling all Amsterdam I/II criteria except for: (1) the earliest age of diagnosis is allowed to be up to 55 years, (2) gastric cancer is included in HNPCC extra-colonic associated tumors [17]. We decided to include these new clinical criteria for the following reasons. First; several authors have previously described delayed onset ages for CRC in MSS-HNPCC families; ranging from 50 to 60 and placing the average $55 \pm 3.8 \quad[7-9,11,12,14-16]$. Secondly, although Amsterdam II criteria do not consider gastric cancer as HNPCC extracolonic associated cancer, association of gastric cancer and HNPCC has been described [27]. Finally, some of our Lynch families fall within these criteria (see Table 1 and supplementary Table 1).

Table 1 Main features of MSS-HNPCC and Lynch populations

\begin{tabular}{lll}
\hline & MSS-HNPCC n $(\%)$ & LYNCH n (\%) \\
\hline $\begin{array}{l}\text { Number of families } \\
\text { Clinical criteria }\end{array}$ & 37 & 50 \\
Amsterdam I & $17(46 \%)$ & $16(32 \%)$ \\
Amsterdam II & $9(24 \%)$ & $28(56 \%)$ \\
High risk & $11(30 \%)$ & $6(12 \%)$ \\
MSI TEST & MSS & MSI-H \\
IHC TEST & Presence & Absence \\
MLH1/PMS2 & Yes & $28(56 \%)$ \\
MSH2/MSH6 & Yes & $22(44 \%)$ \\
MMR GENES TEST & Negative & Positive \\
MLH1 & 0 & $28(56 \%)$ \\
MSH2 & 0 & $18(36 \%)$ \\
MSH6 & 0 & $4(8 \%)$ \\
\hline
\end{tabular}

${ }^{\text {a }}$ All mutations detected in MMR genes were pathogenic and agree with MSI and IHQ results 
All families were included in the cancer risk analysis. Fifty five colorectal tumors from 35 of these families were recruited for the remaining studies; 25 from Amsterdam I families, 13 from Amsterdam II and 17 from HRC families. The average age at diagnosis was $55.1 \pm 12.6$ and $49 \%$ were females. Regarding to Duke's Stage, $49 \%$ were B and $25 \% \mathrm{C}$.

\section{Lynch population}

A total of 50 families were recruited at the Genetic Counseling Unit of our Hospital from 1999 to 2010. All studied tumors were microsatellite instable (MSI), showed abnormal expression of MMR proteins and pathogenic mutation in the corresponding gene was detected. Sixteen families fulfilled Amsterdam I clinical criteria [3], 28 fulfilled Amsterdam II criteria [4] and 6 families fulfilled HRC criteria [17]. Summary of the main features of these families is shown in Table 1 and supplementary Table 1 .

All families were included in the cancer risk analysis. Sixty nine colorectal tumors from 46 of these families were recruited for the remaining studies; 20 from Amsterdam I families, 37 from Amsterdam II and 12 from HRC families. The average age at diagnosis was $45.1 \pm 12.9$, and $44 \%$ were females. Regarding to Dukes' Stage, $46 \%$ were B and $40 \% \mathrm{C}$.

\section{Sporadic CRC population}

A total of 612 consecutive sporadic CRC tumors without cancer family history were included in the molecular testing of KRAS and BRAF. All of them treated at the Oncology Unit of our Hospital during 1999 and 2011. We were able to collect clinical and pathology reports and the follow up of 102 tumors; the average age at diagnosis was $65.1 \pm 10.9$ and $45 \%$ of CRC affected were females, $12 \%$ tumors were Dukes' B staged and 39 \% Dukes' C.

This study was approved by the Institutional Review Board of the Hospital Clínico San Carlos. Informed consent was obtained from each participant. Cancer diagnoses, tumor details and deaths were confirmed by reviewing medical records, pathology reports, or death certificates.

\section{DNA extraction}

Peripheral-blood genomic DNA extraction was performed according to the salting out procedure [28] or with MagnaPure Compact extractor (Roche) according to the manufacturer's recommended protocol. Tumor DNA was obtained from paraffin embedded tissues with a tumor content of more than $80 \%$ as determined by an experienced pathologist from hematoxylin/eosin stained sections. Extractions were performed after digestion with proteinase
$\mathrm{K}$ and purification with phenol/chlorophorm as previously described [29]. Genomic and tumor DNA quantity and quality were assessed with Nanodrop (ND1000).

Microsatellite instability status

Microsatellite instability analysis was performed testing the Bethesda panel of five microsatellite markers (BAT25, BAT26, D2S123, D5S346, and D17S250) [30] in paired tumor-normal DNA samples. Amplification and visualization of microsatellites were achieved as described previously [31]. Tumors were classified as MSS if all markers were stable.

Immunohistochemistry of MLH1, MSH2, MSH6 and PMS2

Immunohistochemistry analysis of MLH1, MSH2, PMS2 and MSH6 proteins was done as described previously [15]. The percentage of positive nuclei was evaluated by two pathologists. Expression of MLH1, MSH2, MSH6 and PMS2 were scored as positive when nuclear staining was observed in at least some tumor cells and negative if the staining was observed in the internal control but not in the tumor cells.

Mutational screening of MLH1, MSH2, and MSH6

Mutation screening included the analysis of all coding sequences and intron/exon boundaries of $M L H 1, M S H 2$, and MSH6 by denaturing gradient gel electrophoresis as previously reported $[32,33]$. In addition, the presence of genomic rearrangements at the $M L H 1, M S H 2, M S H 6$, and PMS2 loci was tested by multiplex ligation-dependent probe amplification with P003 and P008 MRC-Kit (MRCHolland), according to the supplier's instructions.

Mutational analysis in tumor DNA

The c.1799T $>$ A (p.V600E) mutation in $B R A F$ gene was determined by the cobas ${ }^{\circledR} 4800 B R A F$ V600 Mutation test (Roche) according to the manufacturer's recommended protocol.

Detection of mutations at codons 12 and 13 in KRAS gene was achieved by the "Therascreen KRAS RGQ PCR Kit" (QIAGEN) according to the manufacturer's recommended protocol. The method combines allele specific PCR with Scorpion fluorescent probes to detect the most commonly reported KRAS mutations; c.35G $>$ A (p.G12D), c. $35 \mathrm{G}>\mathrm{C} \quad$ (p.G12A), c.34G $>\mathrm{C} \quad$ (p.G12R), c.34G $>\mathrm{T}$ (p.G12C), c.34G $>$ A (p.G12S), c.35G $>$ T (p.G12V) and c.38G $>$ A (p.G13D) by real time PCR (RT-PCR) [34, 35]. Reactions and analysis were carried out in a Light-Cycler $480^{\circledR}$ real-time PCR (LC480) in combination with the 
Light-Cycler ${ }^{\circledR}$ Adapt Software v1.1 (Roche Diagnostics). The mutation-detection limit is estimated to be $1 \%$, according to the manufacturer's manual.

Statistical analysis

All categorical comparisons were done by Chi squared test. Continuous variables were compared by $t$ test. Overall survival plots were calculated by Kaplan-Meier method and significance by Breslow test. Hazard risk (HR) and confidence intervals (CI) were estimated by Cox regression. For survival plots only B or C Dukes' stages were included. All statistics were done with SPSS v15 software.

Cancer incidence evaluation

In order to estimate the cancer incidence in MSS-HNPCC and Lynch populations, reference triad members used for the clinical ascertainment of each family were excluded and only first and second degree relatives were considered. In families with multiple possible triads, those that would include the youngest affected members were selected. A total of 602 relatives belonging to 37 MSS-HNPCC families and 668 relatives belonging to 50 Lynch families were included in the analysis.

Cancer incidences were compared between Lynch and MSS-HNPCC by indirect standardization [36]. Standardized incidence ratio (SIR) for each HNPCC cancer was calculated as the ratio between the observed and the expected number of cases in each population. The later one was calculated by the sum of the products of the number of person-years age/sex group and the corresponding age/sex specific incidences rates for the Spanish population according to the GLOBOCAN database [37]. Differences in cancer incidences between both populations were tested for statistical significance by the Chi squared test.

\section{Results}

We were able to collect clinical and pathology reports and the follow up of 102 sporadic CRC, 55 MSS-HNPCC and
69 Lynch colorectal tumors. Main clinical-pathological features are shown in Table 2.

Morphological analysis

Results about colon location, tumor differentiation degree, presence of mucus and detection of polyps at the time of diagnosis are displayed in Table 2.

Differences in the anatomical distribution of the tumors were significant $(\rho<0.001)$ among all populations; MSSHNPCC tumors were preferably located in the left colon $(60.8 \%)$, Lynch tumors were preferably located in the right colon $(58.3 \%)$ and sporadic tumors were equally distributed along the distal colon and rectum being less frequent the proximal location $(23.8 \%)$.

Sporadic population showed slightly decreased frequency of poorly differentiated tumors compared to the other two populations $(\rho=0.059)$.

The percentage of mucinous tumors in MSS-HNPCC population was not different from that of Lynch tumors and they were greater than sporadic tumors $(\rho=0.008)$.

Regarding to the presence of polyps at the time of diagnosis, almost half of MSS-HNPCC patients had polyps, and it was significantly higher than the other two populations $(\rho=0.027)$.

\section{BRAF/KRAS analysis}

We were able to collect 49, 42 and 612 DNA samples from MSS-HNPCC, Lynch and sporadic tumors for subsequent molecular analysis.

The c.1799T $>$ A (p.V600E) mutation in $B R A F$ was not detected in MSS-HNPCC or in Lynch tumors. However, 4 out of 101 (4\%) sporadic tumors showed such mutation.

Regarding to KRAS somatic mutations, all populations showed similar mutation rates $(48.8 \pm 5.8)$ (Fig. 1a). The c.35G $>$ A (p.G12D), c.38G $>$ A (p.G13D) and c.35G $>$ T (p.G12V) mutations were the most prevalent in the three study populations. However MSS-HNPCC tumors showed greater heterogeneity in the distribution of mutations according to the amino acid changes. The proportion of c.34G $>$ T (p.G12C) was similar in MSS-HNPCC and

Table 2 Summary of clinical-pathological features of MSS-HNPCC, Lynch and sporadic tumors

\begin{tabular}{|c|c|c|c|c|c|c|c|c|c|c|c|c|}
\hline & \multirow[t]{2}{*}{ No. } & \multirow[t]{2}{*}{ Dx age \pm SD } & \multicolumn{4}{|c|}{ Dukes' stage (\%) } & \multicolumn{3}{|c|}{ Location (\%) } & \multirow{2}{*}{$\begin{array}{l}\text { Differentiation } \\
\text { (\% poor) }\end{array}$} & \multirow[t]{2}{*}{ Mucus (\%) } & \multirow[t]{2}{*}{ Polyps (\%) } \\
\hline & & & A & B & $\mathrm{C}$ & $\mathrm{D}$ & Left & Right & Rectum & & & \\
\hline MSS-HNPCC & 55 & $55.1 \pm 12.6$ & 7.5 & 49 & 24.5 & 19 & 60.8 & 23.5 & 15.7 & 11.1 & 31.1 & 45.5 \\
\hline LYNCH & 69 & $45.1 \pm 12.9$ & 6 & 46 & 40 & 8 & 28.3 & 58.3 & 13.3 & 15.4 & 41.5 & 22.4 \\
\hline SP-CRC & 102 & $65.1 \pm 10.9$ & 0 & 12 & 39 & 49 & 40.6 & 23.8 & 35.6 & 4.2 & 14.2 & 11.9 \\
\hline
\end{tabular}

No number of tumors, $S D$ standard deviation 
sporadic tumors but it was not present in Lynch tumors. The percentage of c.35G $>C$ (p.G12A) in MSS-HNPCC was bigger than sporadic tumors and it was not present in Lynch tumors (Fig. 1b). The base change distribution in each population showed similar $\mathrm{G}>\mathrm{A}$ and $\mathrm{G}>\mathrm{T}$ rates (66.4 \pm 5.6 and $28.2 \pm 4.5$ respectively). However $\mathrm{G}>\mathrm{C}$ mutation was not detected in any Lynch tumor and it was significantly increased in MSS-HNPCC tumors $(\rho=0.022)$ (Fig. 1c). KRAS mutation results are also described in supplementary Table 1 .

\section{Survival analysis}

Overall survival plots in patients with B and C Dukes' staged CRC are depicted for each of the study populations in Fig. 2. It should be noted the different survival behavior of MSS-HNPCC at B and C Dukes's stages; overall survival

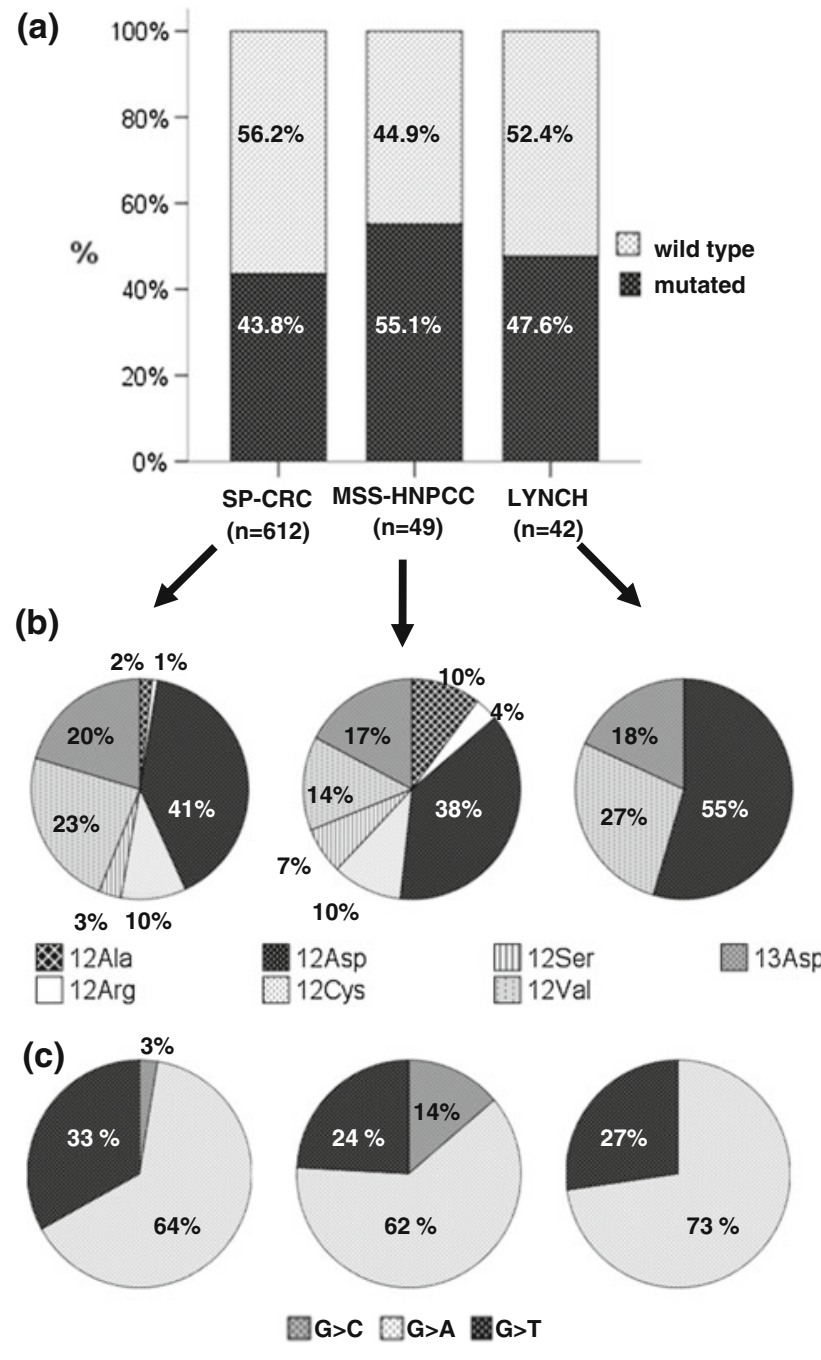

Fig. 1 KRAS somatic mutation spectrum in sporadic, MSS-HNPCC and Lynch tumors. a KRAS somatic mutation rates; b amino acid variation profile; $\mathbf{c}$ nucleotide change profile for B staged MSS-HNPCC is similar to Lynch and significant different from sporadic CRC $(\rho<0.001)$, whereas overall survival for C staged MSS-HNPCC is in between Lynch and sporadic tumors.

Figure 3 shows overall survival for all tumors together according to KRAS status. There is no difference between KRAS mutated and wild type tumors at both Dukes' stages. Further survival analyses attending to the KRAS status and $K R A S$ base change were done in each population but none of them showed statistical differences (data not shown).

Family comparison and cancer risk

The average age at CRC diagnosis was $65.1 \pm 10.9$; $55.1 \pm 12.6$ and $45.1 \pm 12.9$ years respectively (Table 2 ). This result was consistent with previous data showing statistic significance between the 3 populations $(\rho=0.001$ ).

Incidence analyses were done for the most recurrent tumors. SIR calculations and confidence intervals (95\%) for colorectal, endometrial, stomach, kidney, ovary and breast tumors in MSS-HNPCC and Lynch relatives are shown in Table 3. Incidences for colorectal and endometrial cancers were increased in MSS-HNPCC relatives compared to the standard population but decreased when they were compared to Lynch relatives $(\rho<0.0001)$. Incidences for kidney and stomach tumors in MSS-HNPCC relatives were increased compared to the standard population but not different from those in Lynch relatives. All kidney tumors were located in the kidney and most of them were clear cell carcinomas.

\section{Discussion}

In order to better discuss our results with those previously described in other MSS-HNPCC populations, it should be noted the different selection criteria used in different studies. Although most of them [9-14] included Amsterdam I and Amsterdam II criteria for the selection of MSSHNPCC families, two studies [7, 16] are based on the most strict Amsterdam I criteria (FCC-X) and conversely other two $[8,15]$ include the Bethesda criteria [38].

After Lynch diagnosis in families coming from our Genetic Counseling Unit, we found great representation of Amsterdam I families, Amsterdam II, and also Amsterdam like families (fulfilling our own defined HRC criteria) in Lynch positive families. In order to better compare our Lynch families with our MSS-HNPCC families, and to avoid a sample selection bias, we used those three clinical criteria represented in our Lynch positive group for the selection of MSS-HNPCC families.

Despite differences in the selection clinical criteria used in previous studies, there are some features concerning the 
(a)

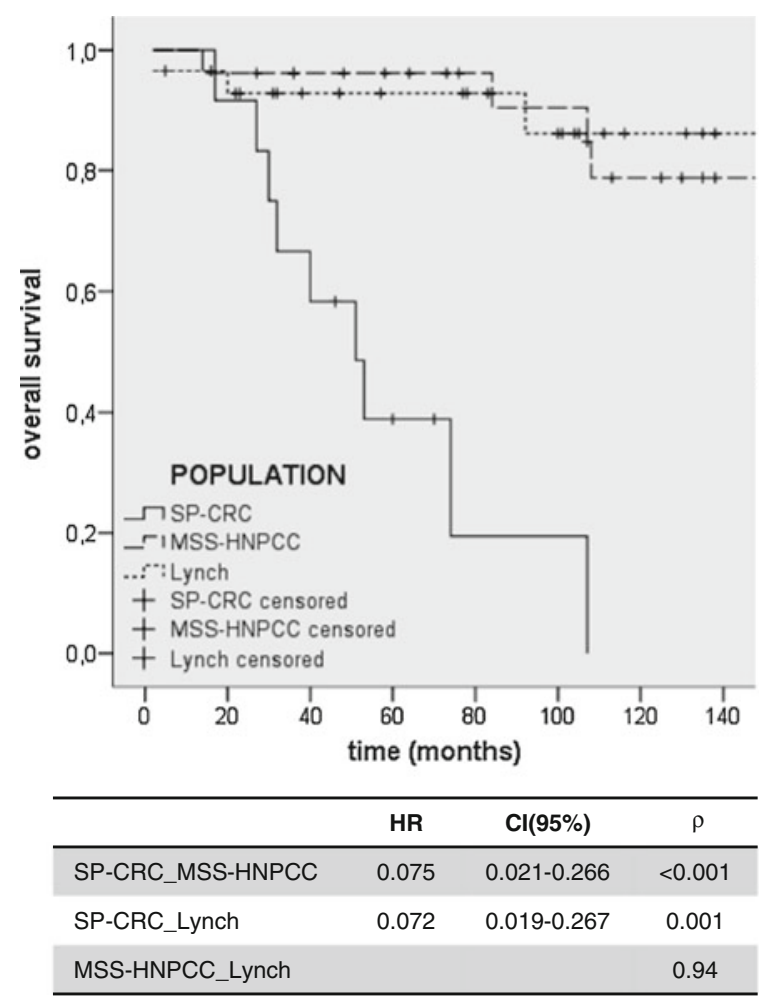

(b)

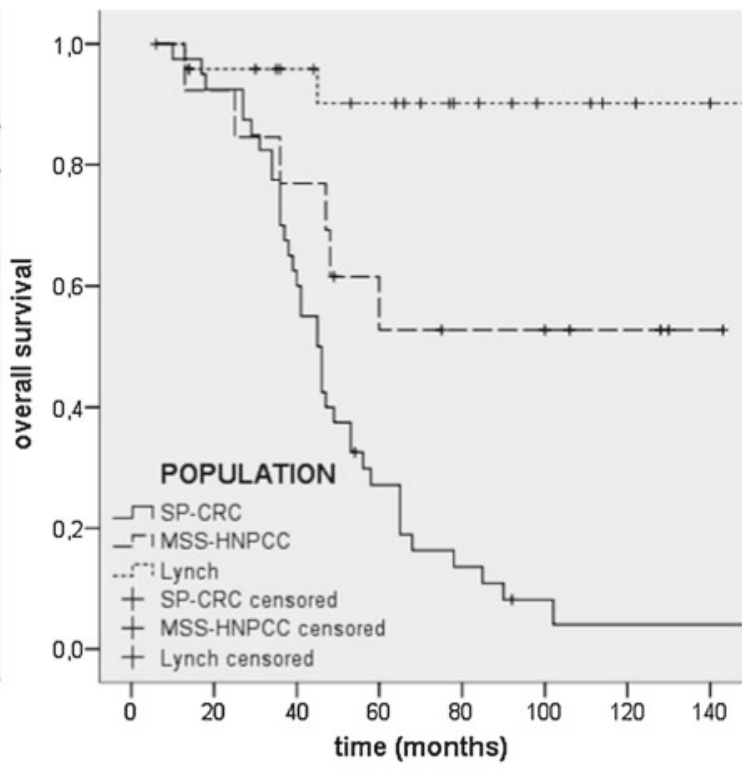

\begin{tabular}{lccc}
\hline & HR & Cl(95\%) & $\rho$ \\
\hline SP-CRC_MSS-HNPCC & 0.33 & $0.14-0.79$ & 0.061 \\
SP-CRC_Lynch & 0.06 & $0.01-0.24$ & $<0.001$ \\
MSS-HNPCC_Lynch & 0.19 & $0.04-0.92$ & 0.03 \\
\hline
\end{tabular}

Fig. 2 Overall survival for MSS-HNPCC, Lynch syndrome and sporadic colorectal cancer patients according to Duke's Stage. a Overall survival for Dukes' B staged tumors; b overall survival for C staged tumors. $H R$ hazard ratio, $C I$ confidence interval, $\rho$ Breslow $p$ value

(a)

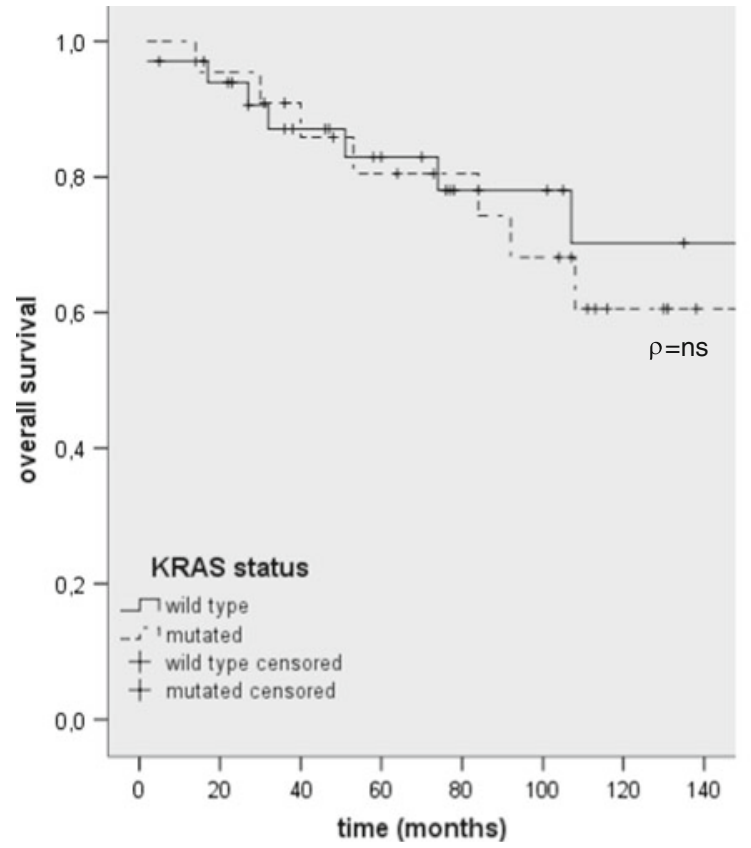

(b)

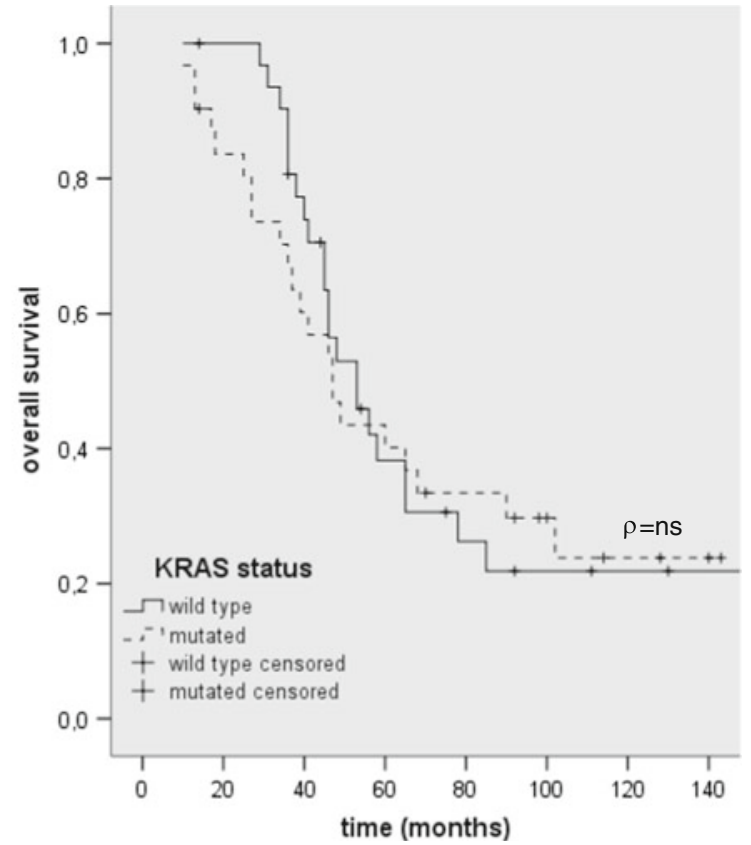

Fig. 3 Overall survival for colorectal cancer patients by KRAS mutational status. a Overall survival for Dukes' B staged tumors; b overall survival for $\mathrm{C}$ staged tumors. $\rho$ Breslow $p$ value, $n s$ no significant differences 
Table 3 Standardized incidence ratio (SIR) of main associated tumors in Lynch and MSS-HNPCC first and second relatives

$n s$ no statistic significance

${ }^{\mathrm{a}} \mathrm{n}$ : number of 1 st and $2 \mathrm{nd}$ degree relatives excluding the reference triad members; ${ }^{b}$ No.: number of tumors observed

\begin{tabular}{|c|c|c|c|c|c|}
\hline \multirow[t]{2}{*}{ Tumour site } & \multicolumn{2}{|c|}{$\mathrm{LYNCH}\left(\mathrm{n}^{\mathrm{a}}=668\right)$} & \multicolumn{2}{|c|}{ MSS-HNPCC $\left(n^{\mathrm{a}}=602\right)$} & \multirow[t]{2}{*}{$\rho$ value } \\
\hline & No. $^{b}$ & $\operatorname{SIR}(95 \% \mathrm{CI})$ & No. ${ }^{b}$ & $\operatorname{SIR}(95 \% \mathrm{CI})$ & \\
\hline Colorectum & 101 & $19.3(15.7-23.5)$ & 37 & $6.6(4.6-9.1)$ & $<0.0001$ \\
\hline Kidney & 5 & $4.4(1.4-10.4)$ & 6 & $5.2(1.9-11.4)$ & ns \\
\hline Stomach & 16 & $10.5(6-17)$ & 8 & $4.9(2.1-9.8)$ & ns \\
\hline Uterus & 31 & $24.2(16.5-34.5)$ & 5 & $4(1.3-9.4)$ & $<0.0001$ \\
\hline Ovary & 8 & $7.8(3.3-15.5)$ & 2 & $2(0.2-7.5)$ & 0.086 \\
\hline Breast & 10 & $1.2(0.6-2.2)$ & 13 & $1.6(0.8-2.7)$ & ns \\
\hline
\end{tabular}

age at CRC diagnosis and tumor morphology that match in all studies including ours. All authors detect an early diagnosis age in MSS-HNPCC compared to sporadic CRC although delayed respect to Lynch syndrome. The CRC diagnosis age ranges from 50 to 60 in different MSSHNPCC populations and our result (55.1) is in the average $(55 \pm 3.8)$ (Table 2). Regarding to tumor characteristics, our results are also consistent with previous ones; MSSHNPCC tumors show preferential distal location (76\%) resembling sporadic tumors $(76 \%)$, there is no difference in the tumor differentiation degree with the other two study populations and they show the highest percentage of cases with adenomas detection at the time of CRC detection (45\%) (Table 2). The increase of polyp detection at time of CRC diagnosis is also described in two previous studies $[14,16]$. One study explains difference in polyp detection between Lynch and MSS-HNPCC by the "aggressive adenoma theory" [39]. According to this theory, Lynch tumors have an accelerated progression from adenoma to carcinoma and the increased detection of polyps in MSSHNPCC tumors correspond to a slower progression [14].

In addition to these data, we wanted to investigate the incidence of CRC and other extracolonic tumors in 1st and 2nd degree relatives. As expected, we observed high SIRs for all HNPCC tumors in Lynch relatives, especially for colorectal and endometrial cancer (Table 3). Furthermore we also found increased rates for HNPCC tumors in MSSHNPCC relatives although in a lesser extent. There is only one previous study analyzing the incidence of other tumors in MSS-HNPCC relatives by SIR [7] in which the authors describe a high incidence of CRC but not for extra-colonic tumors. This divergence of results can be due to the selection criteria used in both studies. Lindor and colleges recruited MSS-HNPCC families fulfilling Amsterdam I criteria (ie, families with inheritance pattern of CRC but not of other extracolonic tumors), in our study we have included Amsterdam I and Amsterdam II families implying the presence of other associated extracolonic tumors. Other studies analyzed the presence of tumors in MSS-HNPCC relatives detecting increased percentages of CRC, endometrial an even stomach [13, 14, 16] but they did not standardized the data. Therefore, our data suggest an increase of HNPPC extra-colonic tumors incidence when Amsterdam II criteria is included in the selection criteria of MSS-HNPCC.

Due to the increasing interest to $B R A F / K R A S$ status in CRC tumors as predictive biomarkers for anti-EGFR therapy [40-43], it becomes important to accurately evaluate $B R A F / K R A S$ mutation rates in different CRC populations.

KRAS mutation rate in sporadic CRC has been estimated around 30-40 \%. Recent detection methodologies, based in allele specific amplifications and RT-PCR [34], have increased the sensitivity of detection in tumor samples. Precisely, the FDA just approved the "Therascreen KRAS RGQ PCR Kit" to determine the KRAS status in metastatic CRC tumors in order to improve the effectiveness of target therapy [26]. In our laboratory, we have carried out the comparison between Therascreen KRAS detection kit and Sanger sequencing detection in a large series of sporadic $\mathrm{CRC}$ and it was revealed an increase of $18 \%$ (from 26 to $44 \%$ ) in the KRAS mutation rate when Therascreen was used [44]. KRAS mutation rates in HNPCC population have been estimated by direct sequencing ranging from $17 \%$ to $47 \%$ in MSS-HNPCC and from 27 to $40 \%$ in Lynch tumors [8-10, 15, 18]. All these rates are lower than those revealed in the present study (55\% of KRAS mutation in MSS-HNPCC and $48 \%$ in Lynch tumors) (Fig. 1a). Our rates are not statistically different between both HNPCC populations and neither when they are compared with the mutation rate in our sporadic population (44\%).

Regarding to the $K R A S$ base mutation profile (Fig. 1c), we observed similar $\mathrm{G}>\mathrm{T}$ and $\mathrm{G}>\mathrm{A}$ change rates in our 3 study populations which are consistent with those described before in HNPCC and sporadic tumors [8, 9, 15, 18]. $\mathrm{G}>\mathrm{C}$ changes are controversial in other MSS-HNPCC populations $[8,9,15]$. In our study we did not detect any $\mathrm{G}>\mathrm{C}$ mutation in Lynch tumors whereas MSS-HNPCC tumors showed the major proportion of $\mathrm{G}>\mathrm{C}$ changes (14\%). Two out of the seven mutation tested by Therascreen involve a $\mathrm{G}>\mathrm{C}$ change $[\mathrm{c} .34 \mathrm{G}>\mathrm{C}$ (p.G12R) and c.35G $>C$ (p.G12A)]. The sum of the frequencies of both mutations involves not more than $8 \%$ of the KRAS somatic mutations found in CRC (COSMIC database; http://cancer. 
sanger.ac.uk/cancergenome/projects/cosmic/). We are working with a relatively small tumor sample size (42 Lynch tumors which 20 showed KRAS mutated) so the absence of $\mathrm{G}>\mathrm{C}$ mutations is not surprising. However is noteworthy the high $\mathrm{G}>\mathrm{C}$ rate in MSS-HNPCC (4 tumors out of 29) that could suggest different KRAS mutation events. We could explain the lack of detection of c.34G $>$ T (p.G12C) KRAS mutations in Lynch tumors for the same reason as above. In addition, it is revealed a general increase of mutation detection in the 3 study populations when a more sensitive methodology is used instead direct sequencing technology. So our results are the first updated KRAS mutation rates in colorectal tumors from HNPCC families.

We also tested the presence of c.1799T $>$ A (p.V600E) $B R A F$ mutation in the three study populations. We did not detect this mutation in any Lynch or MSS-HNPCC tumor, these results were expected since $B R A F$ mutations are strongly associated to the " $\mathrm{CpG}$ island methylator phenotype" (CIMP) in sporadic CRC [45, 46]. Two previous studies describe certain percentage of $B R A F$ mutation in MSS-HNPCC tumors [8, 15], but ascertainment criteria use in both studies includes Bethesda clinical criteria [38] which are much less stringent than Amsterdam criteria and this could increase the heterogeneity of the group allowing the inclusion of non-familial cases. Two other studies based on MSS-HNPCC families selected according to Amsterdam I/II criteria did not observe $B R A F$ mutations in any of the tumors tested $[10,18]$ which is consistent with our results and they dismiss the involvement of CIMP CRC in our population.

Finally, we carried out overall survival analyses in patients with B and C Dukes' staged colorectal tumors from study populations (Fig. 2). Data suggests a better prognosis of MSS-HNPCC than sporadic tumors at both Dukes' stages studied. The most accepted hypothesis to explain the known increased survival in Lynch tumors is the ability to express frameshift peptides (FSPs) with immunogenic properties leading to an immune response against tumor cells [47]. This ability is due to the lack of Mismatch Repair function in these tumors (MSI). One of the main characteristics of MSS-HNPCC tumors is precisely the correct function of the mismatch repair system, so no FSPs due to microsatellite instability are expressed and the good prognosis in MSS-HNPCC tumors cannot be explain by this hypothesis. Looking at survival plots, MSSHNPCC B staged tumors show a very similar survival to Lynch whereas $\mathrm{C}$ staged tumors show an intermediate survival between sporadic and Lynch $\mathrm{C}$ tumors. This could suggest that the better prognosis in this group could be due to different driver mutations involved in dissemination and metastasis [48]. Anyway, this is the first evidence of good prognosis of MSS-HNPCC tumors and further survival analyses of largest populations are needed to confirm this.
Further overall survival analyses were carried out according to the KRAS status and no significant differences were found when all tumors were analyzed together according to Dukes' stages B or C (Fig. 3). Neither difference was found when analyzing the 3 populations separately (data not shown). These results are not surprising since $K R A S$ role on CRC prognosis still remains controversial [49, 50]. The RASCAL II study [51] was conducted in 4,268 colorectal tumors to explore the role of KRAS mutations related to Dukes' stages. The analysis concluded that, of all possible mutations on codons 12 and 13, only the c.35G $>\mathrm{T}$ (p.G12V) transversion had a significant poor failure-free and overall survival in Dukes' $\mathrm{C}$ stage but not in B. Our results do not support the role of KRAS as CRC prognostic factor in any B or C Dukes' stages when all $K R A S$ mutation types are taking in together. Anyway our small sample size make impossible to conduct the analysis by specific $K R A S$ mutation classes. It would be desirable to conduct the analysis by specific KRAS mutations classes; however it has not been possible due to the scarcity of such families.

Summarizing, our MSS-HNPCC population agrees with other described MSS-HNPCC populations in early colorectal cancer age at diagnosis, preferential distal tumor location, frequent presence of polyps and increased CRC incidence in relatives. Improved overall survival and increased HNPCC extra-colonic tumors incidence are new clinical features of MSS-HNPCC families. This fact could help the genetic and medical counseling of these families. Furthermore, updated and increased KRAS mutation rates in MSS-HNPCC, Lynch and sporadic CRC are given for the first time using high sensitive methodology. This is important since resistance to anti EGFR therapies have been described in tumors harboring KRAS mutations.

\section{Conclusions}

This study gives, for the first time, MSS-HNPCC overall survival data suggesting a better prognosis than Sporadic although lower than Lynch syndrome. Identification of good prognosis of these families is relevant for clinicians when making decisions.

Our incidence analysis shows a slight but significant increase of extracolonic HNPCC tumors in first and second degree relatives when Amsterdam II is included in the selection criteria of MSS-HNPCC families. This fact becomes important in the Genetic Counseling of these families suggesting the need for more extensive medical monitoring including the screening for other associated cancers besides the CRC.

Furthermore, updated and increased KRAS mutation rates in MSS-HNPCC, Lynch and sporadic CRC are given 
for the first time using high sensitive methodology. This is important since resistance to anti EGFR therapies have been described in tumors harboring KRAS mutations.

Nevertheless, our study is limited because it was a retrospective study and had a small sample size. Therefore, additional studies in different and larger population should be achieved in order to confirm our findings.

Acknowledgments The present study was supported by the "Instituto de Salud Carlos III" (FEDER) research Grants FIS 10/00641 and RTICC 06/0020/0021, Spanish Ministry of Science.

Conflict of interest All authors state that they have no conflicts of interest.

\section{References}

1. Watson P, Lynch HT (1993) Extracolonic cancer in hereditary nonpolyposis colorectal cancer. Cancer 71(3):677-685

2. Lynch HT, Smyrk T, Lynch JF (1996) Overview of natural history, pathology, molecular genetics and management of HNPCC (Lynch syndrome). Int J Cancer 69(1):38-43

3. Vasen HF, Mecklin JP, Khan PM, Lynch HT (1991) The international collaborative group on hereditary non-polyposis colorectal cancer (ICG-HNPCC). Dis Colon Rectum 34(5):424-425

4. Vasen HF, Watson P, Mecklin JP, Lynch HT (1999) New clinical criteria for hereditary nonpolyposis colorectal cancer (HNPCC, Lynch syndrome) proposed by the international collaborative group on HNPCC. Gastroenterology 116(6):1453-1456

5. Peltomaki P, Vasen H (2004) Mutations associated with HNPCC predisposition-update of ICG-HNPCC/INSiGHT mutation database. Dis Markers 20(4-5):269-276

6. Lynch HT, de la Chapelle A (1999) Genetic susceptibility to nonpolyposis colorectal cancer. J Med Genet 36(11):801-818

7. Lindor NM, Rabe K, Petersen GM, Haile R, Casey G, Baron J, Gallinger S, Bapat B, Aronson M, Hopper J, Jass J, LeMarchand L, Grove J, Potter J, Newcomb P, Terdiman JP, Conrad P, Moslein G, Goldberg R, Ziogas A, Anton-Culver H, de Andrade M, Siegmund K, Thibodeau SN, Boardman LA, Seminara D (2005) Lower cancer incidence in Amsterdam-I criteria families without mismatch repair deficiency: familial colorectal cancer type X. JAMA 293(16):1979-1985

8. Abdel-Rahman WM, Ollikainen M, Kariola R, Jarvinen HJ, Mecklin JP, Nystrom-Lahti M, Knuutila S, Peltomaki P (2005) Comprehensive characterization of HNPCC-related colorectal cancers reveals striking molecular features in families with no germline mismatch repair gene mutations. Oncogene 24(9): $1542-1551$

9. Francisco I, Albuquerque C, Lage P, Belo H, Vitoriano I, Filipe B, Claro I, Ferreira S, Rodrigues P, Chaves P, Leitao CN, Pereira AD (2011) Familial colorectal cancer type $X$ syndrome: two distinct molecular entities? Fam Cancer 10(4):623-631

10. Goel A, Xicola RM, Nguyen TP, Doyle BJ, Sohn VR, Bandipalliam P, Rozek LS, Reyes J, Cordero C, Balaguer F, Castells A, Jover R, Andreu M, Syngal S, Boland CR, Llor X (2010) Aberrant DNA methylation in hereditary nonpolyposis colorectal cancer without mismatch repair deficiency. Gastroenterology 138(5):1854-1862

11. Klarskov L, Holck S, Bernstein I, Nilbert M (2012) Hereditary colorectal cancer diagnostics: morphological features of familial colorectal cancer type X versus Lynch syndrome. J Clin Pathol 65(4):352-356

12. Koh PK, Kalady M, Skacel M, Fay S, McGannon E, Shenal J, Arroyo L, Toderick K, Church J (2010) Familial colorectal cancer type X: polyp burden and cancer risk stratification via a family history score. ANZ J Surg 81(7-8):537-542

13. Llor X, Pons E, Xicola RM, Castells A, Alenda C, Pinol V, Andreu M, Castellvi-Bel S, Paya A, Jover R, Bessa X, Giros A, Roca A, Gassull MA (2005) Differential features of colorectal cancers fulfilling Amsterdam criteria without involvement of the mutator pathway. Clin Cancer Res 11(20):7304-7310

14. Mueller-Koch Y, Vogelsang H, Kopp R, Lohse P, Keller G, Aust D, Muders M, Gross M, Daum J, Schiemann U, Grabowski M, Scholz M, Kerker B, Becker I, Henke G, Holinski-Feder E (2005) Hereditary non-polyposis colorectal cancer: clinical and molecular evidence for a new entity of hereditary colorectal cancer. Gut 54(12):1733-1740

15. Sanchez-de-Abajo A, de la Hoya M, van Puijenbroek M, Tosar A, Lopez-Asenjo JA, Diaz-Rubio E, Morreau H, Caldes T (2007) Molecular analysis of colorectal cancer tumors from patients with mismatch repair proficient hereditary nonpolyposis colorectal cancer suggests novel carcinogenic pathways. Clin Cancer Res 13(19):5729-5735

16. Valle L, Perea J, Carbonell P, Fernandez V, Dotor AM, Benitez J, Urioste M (2007) Clinicopathologic and pedigree differences in Amsterdam I-positive hereditary nonpolyposis colorectal cancer families according to tumor microsatellite instability status. J Clin Oncol 25(7):781-786

17. Garre P, Briceno V, Xicola RM, Doyle BJ, de la Hoya M, Sanz J, Llovet P, Pescador P, Puente J, Diaz-Rubio E, Llor X, Caldes T (2011) Analysis of the oxidative damage repair genes NUDT1, OGG1, and MUTYH in patients from mismatch repair proficient HNPCC families (MSS-HNPCC). Clin Cancer Res 17(7):17011712

18. Oliveira C, Westra JL, Arango D, Ollikainen M, Domingo E, Ferreira A, Velho S, Niessen R, Lagerstedt K, Alhopuro P, Laiho $\mathrm{P}$, Veiga I, Teixeira MR, Ligtenberg M, Kleibeuker JH, Sijmons RH, Plukker JT, Imai K, Lage P, Hamelin R, Albuquerque C, Schwartz S Jr, Lindblom A, Peltomaki P, Yamamoto H, Aaltonen LA, Seruca R, Hofstra RM (2004) Distinct patterns of KRAS mutations in colorectal carcinomas according to germline mismatch repair defects and hMLH1 methylation status. Hum Mol Genet 13(19):2303-2311

19. Goel A, Nagasaka T, Arnold CN, Inoue T, Hamilton C, Niedzwiecki D, Compton C, Mayer RJ, Goldberg R, Bertagnolli MM, Boland CR (2007) The CpG island methylator phenotype and chromosomal instability are inversely correlated in sporadic colorectal cancer. Gastroenterology 132(1):127-138

20. Boland CR, Goel A (2010) Microsatellite instability in colorectal cancer. Gastroenterology 138(6):2073-2087, e2073

21. Vaughn CP, Zobell SD, Furtado LV, Baker CL, Samowitz WS (2011) Frequency of KRAS, BRAF, and NRAS mutations in colorectal cancer. Genes Chromosomes Cancer 50(5):307-312

22. Domingo E, Laiho P, Ollikainen M, Pinto M, Wang L, French AJ, Westra J, Frebourg T, Espin E, Armengol M, Hamelin R, Yamamoto H, Hofstra RM, Seruca R, Lindblom A, Peltomaki P, Thibodeau SN, Aaltonen LA, Schwartz S Jr (2004) BRAF screening as a low-cost effective strategy for simplifying HNPCC genetic testing. J Med Genet 41(9):664-668

23. Simi L, Pratesi N, Vignoli M, Sestini R, Cianchi F, Valanzano R, Nobili S, Mini E, Pazzagli M, Orlando C (2008) High-resolution melting analysis for rapid detection of KRAS, BRAF, and PIK3CA gene mutations in colorectal cancer. Am J Clin Pathol 130(2):247-253

24. Parameswaran P, Jalili R, Tao L, Shokralla S, Gharizadeh B, Ronaghi M, Fire AZ (2007) A pyrosequencing-tailored 
nucleotide barcode design unveils opportunities for large-scale sample multiplexing. Nucleic Acids Res 35(19):e130

25. Franklin WA, Haney J, Sugita M, Bemis L, Jimeno A, Messersmith WA (2010) KRAS mutation: comparison of testing methods and tissue sampling techniques in colon cancer. J Mol Diagn 12(1):43-50

26. Harbison CT, Horak CE, Ledeine JM, Mukhopadhyay P, Malone DP, O'Callaghan C, Jonker DJ, Karapetis CS, Khambata-Ford S, Gustafson N, Trifan OC, Chang SC, Ravetto F, Iv GA (2013) Validation of companion diagnostic for detection of mutations in codons 12 and 13 of the KRAS gene in patients with metastatic colorectal cancer: analysis of the NCIC CTG CO.17 trial. Arch Pathol Lab Med 137(6):820-827

27. Win AK, Lindor NM, Young JP, Macrae FA, Young GP, Williamson E, Parry S, Goldblatt J, Lipton L, Winship I, Leggett B, Tucker KM, Giles GG, Buchanan DD, Clendenning M, Rosty C, Arnold J, Levine AJ, Haile RW, Gallinger S, Le Marchand L, Newcomb PA, Hopper JL, Jenkins MA (2012) Risks of primary extracolonic cancers following colorectal cancer in Lynch syndrome. J Natl Cancer Inst 104(18):1363-1372

28. Miller SA, Dykes DD, Polesky HF (1988) A simple salting out procedure for extracting DNA from human nucleated cells. Nucleic Acids Res 16(3):1215

29. de La Hoya M, Diaz-Rubio E, Caldes T (1999) Denaturing gradient gel electrophoresis-based analysis of loss of heterozygosity distinguishes nonobvious, deleterious BRCA1 variants from nonpathogenic polymorphisms. Clin Chem 45(11):2028-2030

30. Boland CR, Thibodeau SN, Hamilton SR, Sidransky D, Eshleman JR, Burt RW, Meltzer SJ, Rodriguez-Bigas MA, Fodde R, Ranzani GN, Srivastava S (1998) A National Cancer Institute Workshop on Microsatellite Instability for cancer detection and familial predisposition: development of international criteria for the determination of microsatellite instability in colorectal cancer. Cancer Res 58(22):5248-5257

31. Caldes T, Godino J, Sanchez A, Corbacho C, De la Hoya M, Lopez Asenjo J, Saez C, Sanz J, Benito M, Ramon YCS, DiazRubio E (2004) Immunohistochemistry and microsatellite instability testing for selecting MLH1, MSH2 and MSH6 mutation carriers in hereditary non-polyposis colorectal cancer. Oncol Rep 12(3):621-629

32. Caldes T, Godino J, de la Hoya M, Garcia Carbonero I, Perez Segura P, Eng C, Benito M, Diaz-Rubio E (2002) Prevalence of germline mutations of MLH1 and MSH2 in hereditary nonpolyposis colorectal cancer families from Spain. Int $\mathbf{J}$ Cancer 98(5):774-779

33. Sanchez de Abajo A, de la Hoya M, Tosar A, Godino J, Fernandez JM, Asenjo JL, Villamil BP, Segura PP, Diaz-Rubio E, Caldes T (2005) Low prevalence of germline hMSH6 mutations in colorectal cancer families from Spain. World J Gastroenterol 11(37):5770-5776

34. Thelwell N, Millington S, Solinas A, Booth J, Brown T (2000) Mode of action and application of Scorpion primers to mutation detection. Nucleic Acids Res 28(19):3752-3761

35. Newton CR, Graham A, Heptinstall LE, Powell SJ, Summers C, Kalsheker N, Smith JC, Markham AF (1989) Analysis of any point mutation in DNA. The amplification refractory mutation system (ARMS). Nucleic Acids Res 17(7):2503-2516

36. Esteve J, Benhamou E, Raymond L (1994) Techniques for the analysis of cancer risk. In: IARC, WHO (eds) Statistical methods in cancer research. Volume IV. Descriptive epidemiology, vol 128. IARC Sci Publ, Lyon, pp 49-104

37. Ferlay J, Shin HR, Bray F, Forman D, Mathers C, Parkin DM (2010) Estimates of worldwide burden of cancer in 2008: GLOBOCAN. Int J Cancer 127(12):2893-2917

38. Umar A, Boland CR, Terdiman JP, Syngal S, de la Chapelle A, Ruschoff J, Fishel R, Lindor NM, Burgart LJ, Hamelin R,
Hamilton SR, Hiatt RA, Jass J, Lindblom A, Lynch HT, Peltomaki P, Ramsey SD, Rodriguez-Bigas MA, Vasen HF, Hawk ET, Barrett JC, Freedman AN, Srivastava S (2004) Revised Bethesda Guidelines for hereditary nonpolyposis colorectal cancer (Lynch syndrome) and microsatellite instability. J Natl Cancer Inst 96(4):261-268

39. Lynch HT, Smyrk T, Jass JR (1995) Hereditary nonpolyposis colorectal cancer and colonic adenomas: aggressive adenomas? Semin Surg Oncol 11(6):406-410

40. Allegra CJ, Jessup JM, Somerfield MR, Hamilton SR, Hammond EH, Hayes DF, McAllister PK, Morton RF, Schilsky RL (2009) American Society of Clinical Oncology provisional clinical opinion: testing for KRAS gene mutations in patients with metastatic colorectal carcinoma to predict response to anti-epidermal growth factor receptor monoclonal antibody therapy. J Clin Oncol 27(12):2091-2096

41. Karapetis CS, Khambata-Ford S, Jonker DJ, O'Callaghan CJ, Tu D, Tebbutt NC, Simes RJ, Chalchal H, Shapiro JD, Robitaille S, Price TJ, Shepherd L, Au HJ, Langer C, Moore MJ, Zalcberg JR (2008) K-ras mutations and benefit from cetuximab in advanced colorectal cancer. N Engl J Med 359(17):1757-1765

42. Amado RG, Wolf M, Peeters M, Van Cutsem E, Siena S, Freeman DJ, Juan T, Sikorski R, Suggs S, Radinsky R, Patterson SD, Chang DD (2008) Wild-type KRAS is required for panitumumab efficacy in patients with metastatic colorectal cancer. J Clin Oncol 26(10):1626-1634

43. Febbo PG, Ladanyi M, Aldape KD, De Marzo AM, Hammond ME, Hayes DF, Iafrate AJ, Kelley RK, Marcucci G, Ogino S, Pao W, Sgroi DC, Birkeland ML (2011) NCCN Task force report: evaluating the clinical utility of tumor markers in oncology. J Natl Compr Canc Netw 9(Suppl 5):S1-32; quiz S33

44. Bando I, Cillero L, Sanz-Ortega J, Llovet P, Pescador P, Ferrer M, de la Hoya M, Sastre J, García ED, Caldés T (2012) Study of KRAS new predictive marker in a clinical laboratory. Clin Transl Oncol 14(12):937-942

45. Weisenberger DJ, Siegmund KD, Campan M, Young J, Long TI, Faasse MA, Kang GH, Widschwendter M, Weener D, Buchanan D, Koh H, Simms L, Barker M, Leggett B, Levine J, Kim M, French AJ, Thibodeau SN, Jass J, Haile R, Laird PW (2006) CpG island methylator phenotype underlies sporadic microsatellite instability and is tightly associated with BRAF mutation in colorectal cancer. Nat Genet 38(7):787-793

46. Kambara T, Simms LA, Whitehall VL, Spring KJ, Wynter CV, Walsh MD, Barker MA, Arnold S, McGivern A, Matsubara N, Tanaka N, Higuchi T, Young J, Jass JR, Leggett BA (2004) BRAF mutation is associated with DNA methylation in serrated polyps and cancers of the colorectum. Gut 53(8):1137-1144

47. Drescher KM, Sharma P, Lynch HT (2010) Current hypotheses on how microsatellite instability leads to enhanced survival of Lynch syndrome patients. Clin Dev Immunol 2010:170432

48. Ortega P, Moran A, de Juan C, Frias C, Hernandez S, LopezAsenjo JA, Sanchez-Pernaute A, Torres A, Iniesta P, Benito M (2008) Differential Wnt pathway gene expression and E-cadherin truncation in sporadic colorectal cancers with and without microsatellite instability. Clin Cancer Res 14(4):995-1001

49. Yokota T (2012) Are KRAS/BRAF mutations potent prognostic and/or predictive biomarkers in colorectal cancers? Anticancer Agents Med Chem 12(2):163-171

50. Castagnola P, Giaretti W (2005) Mutant KRAS, chromosomal instability and prognosis in colorectal cancer. Biochim Biophys Acta 1756(2):115-125

51. Andreyev HJ, Norman AR, Cunningham D, Oates J, Dix BR, Iacopetta BJ, Young J, Walsh T, Ward R, Hawkins N, Beranek M, Jandik P, Benamouzig R, Jullian E, Laurent-Puig P, Olschwang S, Muller O, Hoffmann I, Rabes HM, Zietz C, Troungos C, Valavanis C, Yuen ST, Ho JW, Croke CT, O'Donoghue DP, 
Giaretti W, Rapallo A, Russo A, Bazan V, Tanaka M, Omura K, Azuma T, Ohkusa T, Fujimori T, Ono Y, Pauly M, Faber C, Glaesener R, de Goeij AF, Arends JW, Andersen SN, Lovig T, Breivik J, Gaudernack G, Clausen OP, De Angelis PD, Meling GI, Rognum TO, Smith R, Goh HS, Font A, Rosell R, Sun XF, Zhang H, Benhattar J, Losi L, Lee JQ, Wang ST, Clarke PA, Bell
S, Quirke P, Bubb VJ, Piris J, Cruickshank NR, Morton D, Fox JC, Al-Mulla F, Lees N, Hall CN, Snary D, Wilkinson K, Dillon D, Costa J, Pricolo VE, Finkelstein SD, Thebo JS, Senagore AJ, Halter SA, Wadler S, Malik S, Krtolica K, Urosevic N (2001) Kirsten ras mutations in patients with colorectal cancer: the 'RASCAL II' study. Br J Cancer 85(5):692-696 